\title{
Biogenic amines in Italian Pecorino cheese
}

\section{Maria Schirone*, Rosanna Tofalo, Pierina Visciano, Aldo Corsetti and Giovanna Suzzi}

Department of Food Science, University of Teramo, Teramo, Italy

\section{Edited by:}

Sandra Torriani, Università degli Studi di Verona, Italy

Reviewed by:

Margarita Garriga, Institute for Food Research and Technology, Spain

Antonio Valero, University of Cordoba, Spain

\section{${ }^{*}$ Correspondence:}

Maria Schirone, Department of Food Science, University of Teramo, 64023 Mosciano Sant'Angelo, Teramo, Italy. e-mail:mschirone@unite.it
The quality of distinctive artisanal cheeses is closely associated with the territory of production and its traditions. Pedoclimatic characteristics, genetic autochthonous variations, and anthropic components create an environment so specific that it would be extremely difficult to reproduce elsewhere. Pecorino cheese is included in this sector of the market and is widely diffused in Italy ( 62.000t of production in 2010). Pecorino is a common name given to indicate Italian cheeses made exclusively from pure ewes' milk characterized by a high content of fat matter and it is mainly produced in the middle and south of Italy by traditional procedures from raw or pasteurized milk. The microbiota plays a major role in the development of the organoleptic characteristics of the cheese but it can also be responsible for the accumulation of undesirable substances, such as biogenic amines (BA). Bacterial amino acid decarboxylase activity and BA content have to be investigated within the complex microbial community of raw milk cheese for different cheese technologies. The results emphasize the necessity of controlling the indigenous bacterial population responsible for high production of BA and the use of competitive adjunct cultures could be suggested. Several factors can contribute to the qualitative and quantitative profiles of BA's in Pecorino cheese such as environmental hygienic conditions, $\mathrm{pH}$, salt concentration, water activity, fat content, pasteurization of milk, decarboxylase microorganisms, starter cultures, temperature and time of ripening, storage, part of the cheese (core, edge), and the presence of cofactor (pyridoxal phosphate, availability of aminases and deaminases). In fact physico-chemical parameters seem to favor biogenic amine-positive microbiota; both of these environmental factors can easily be modulated, in order to control growth of undesirable microorganisms. Generally, the total content of BA's in Pecorino cheeses can range from about $100-2400 \mathrm{mg} / \mathrm{kg}$, with a prevalence of toxicologically important BA's, tyramine and histamine. The presence of BA is becoming increasingly important to consumers and cheese-maker alike, due to the potential threats of toxicity to humans and consequent trade implications.

Keywords: Italian ewe cheese, microbial groups, biogenic amines

\section{INTRODUCTION}

The name Pecorino is commonly given to Italian cheeses made exclusively from pure ewes' milk and it has in most cases a protected designation of origin or PDO status. Generally this type of cheese is produced in the middle and south of Italy by a traditional procedure, characterized by a different ripening time ranging between 8 and 12 months (Di Cagno et al., 2003). The most popular Pecorino cheeses, such as Pecorino Romano, Fiore Sardo, Canestrato Pugliese, Pecorino Abruzzese, are usually made from raw or pasteurized milk which is inoculated with natural cultures, "scotta fermento," which is produced by acidifying the "scotta," the whey obtained from the manufacture of Ricotta (Di Cagno et al., 2003; Figure 1). The natural whey cultures are composed mainly of thermophilic lactic acid bacteria (LAB), such as Streptococcus thermophilus, Lactobacillus delbrueckii subsp. lactis, and Lactobacillus helveticus. The milk is coagulated at $34-39^{\circ} \mathrm{C}$ adding liquid or powder calf rennet, lamb paste rennet, or pig rennet only for Pecorino di Farindola. After cutting the coagulum, the curds are cooked at $45^{\circ} \mathrm{C}$ for $5-10 \mathrm{~min}$. The curds removed from the vats are placed in traditional and different molds, pressed manually, and ripened from 4 to 18 months.
However, in spite of these varieties there are many other typologies of Pecorino (Table 1) produced throughout the Italian territory according to local or regional costumes, also characterized by a shorter ripening time (1-2 months), semi-hard consistency, but low flavor and aroma (Caridi et al., 2003).

For this reason, a differentiation as well as the reduction of the ripening time can positively influence the consumption of these products. In fact the consumer generally prefers sweet flavor which is the result of short ripening (Gobbetti, 2004). More specifically, traditional products can take advantage from variants form specific attributes.

The principal technological features of more representative Pecorino cheeses are shown in Table 2.

Each unique combination of ingredients and processing parameters leads to a specific type of cheese with unique properties. In fact, the use of raw milk and natural thermophilic starters, cooking of the curd to a high temperature, long ripening, and generally, an ancient tradition are common features to most of Pecorino cheeses.

The particular flavor and typical organoleptic properties of Pecorino cheeses are associated with specific attributes of milk and 


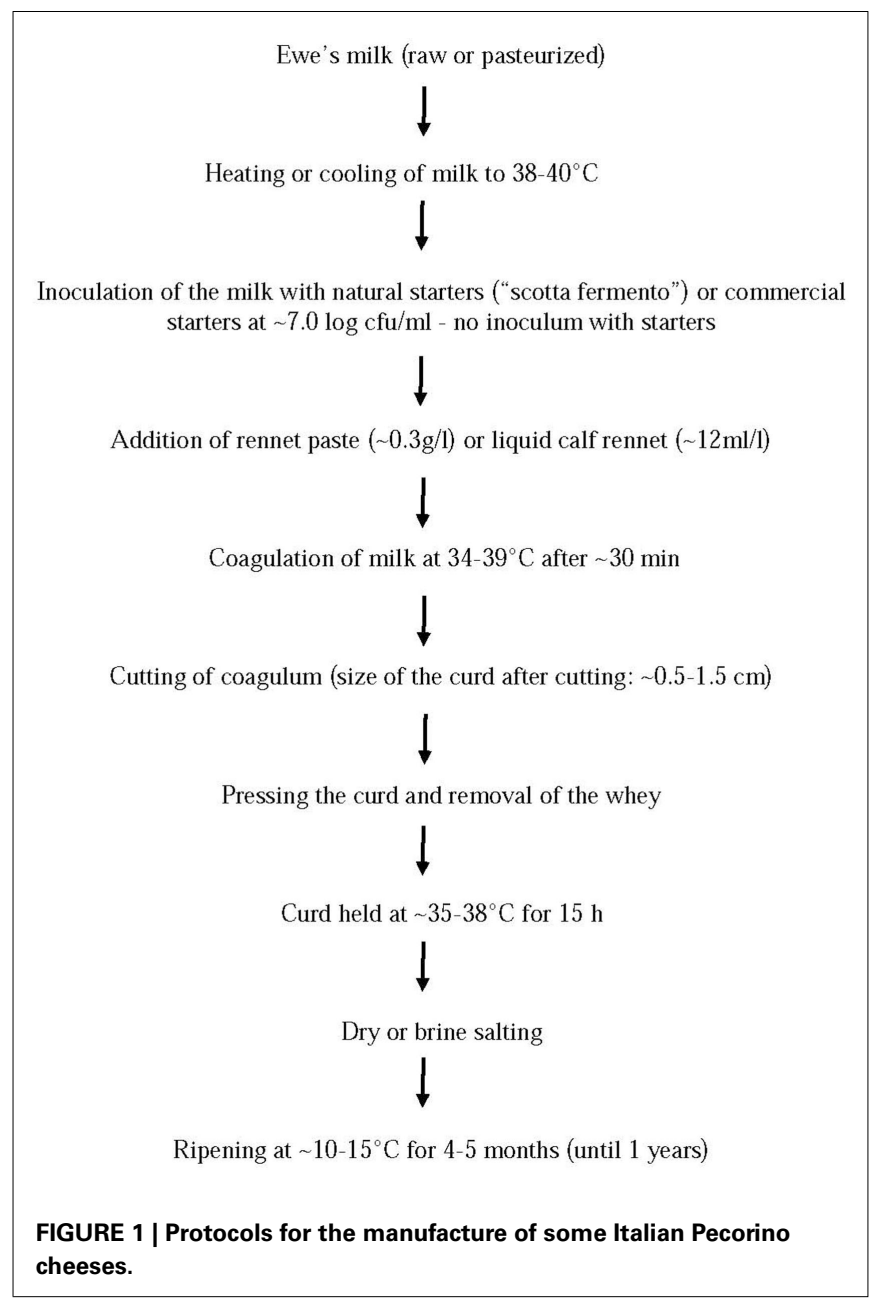

the natural microbiota responsible for fermentation and ripening processes (Corroler et al., 1998; Beresford et al., 2001). The artisanal cheeses have different and typical microbial population dynamics related to the production technology and geographic area of origin, with a microbiota quite heterogeneous (Poznanski et al., 2004).

The formation of large amounts of biogenic amines (BA) on this kind of cheese during the ripening process is allowed by some conditions, such as the availability of free amino acids produced as an outcome of proteolysis and viability of microorganisms possessing amino acid decarboxylating activity. Many genera of food bacteria are responsible of this characteristic (Suzzi and Gardini, 2003). Lactobacilli are considered producer of histamine, tyramine, and putrescine, whereas enterococci are considered tyramine formers and enterobacteria cadaverine and putrescine producers.

\section{THE MICROBIAL GROUPS OF PECORINO}

The microbial composition of raw milk of Pecorino cheeses is generally within the limits reported by different authors (Clementi et al., 1994; Ricci et al., 1995; Gobbetti et al., 1997). Total mesophilic bacteria can range from $10^{6}$ to $10^{7} \mathrm{cfu} / \mathrm{g}$, micrococci and coagulase negative staphylococci are present at $10^{3}$ to $10^{4} \mathrm{cfu} / \mathrm{g}$, such
Table 1 | List of some Italian Pecorino cheeses.

\begin{tabular}{|c|c|}
\hline $\begin{array}{l}\text { Production } \\
\text { region }\end{array}$ & Variety \\
\hline Abruzzo & $\begin{array}{l}\text { Pecorino Abruzzese, Pecorino di Farindola, Cacio } \\
\text { marcetto, Canestrato di Castel del Monte }\end{array}$ \\
\hline Molise & Pecorino di Capracotta, Pecorino del Sannio \\
\hline Calabria & $\begin{array}{l}\text { Pecorino del Monte Poro, Pecorino Calabrese, Pecorino } \\
\text { di Vezzano }\end{array}$ \\
\hline Basilicata & Pecorino del Pollino \\
\hline Campania & $\begin{array}{l}\text { Pecorino Bagnolese, Pecorino di Carmasciano, Pecorino } \\
\text { di Laticauda, Casu ri pecora, Pecorino Campano }\end{array}$ \\
\hline Sicily & Pecorino Pepato, Primusali \\
\hline Sardinia & Pecorino di Nule, Pecorino di Osilo \\
\hline Umbria & Pecorino di Norcia, Pecorino Umbro \\
\hline Tuscany & $\begin{array}{l}\text { Pecorino Senese, Pecorino di Pistoia, Pecorino del } \\
\text { Casentino, Pecorino del Parco di Migliarino-San Rossore, } \\
\text { Pecorino Massese, Pecorino Baccellone, Pecorino } \\
\text { Pisano, Pecorino di Pienza, Abbucciato Aretino }\end{array}$ \\
\hline Apulia & Pecorino di Maglie, Pecorino Brindisino \\
\hline Emilia-Romagna & $\begin{array}{l}\text { Pecorino del Pastore, Pecorino dell'Appennino Reggiano, } \\
\text { Pecorino di Palesio, Pecorino di Vergato }\end{array}$ \\
\hline Piedmont & Pecorino di Bagnolo \\
\hline Liguria & Pecorino di Malga \\
\hline Marche & Pecorino in Botte \\
\hline Veneto & Pecorino dei Berici, Pecorino Veneto \\
\hline Lazio & $\begin{array}{l}\text { Pecorino di Picinisco, Pecorino della Sabina, Pecorino di } \\
\text { Amatrice, Pecorino del Viterbese }\end{array}$ \\
\hline
\end{tabular}

as Enterobacteriaceae and yeasts. Enterococci, representing a typical microbiota of ewes' raw milk, are present from $10^{2}$ to $10^{3} \mathrm{cfu} / \mathrm{g}$. As expected LAB are detected from $10^{2}$ to $10^{5} \mathrm{cfu} / \mathrm{g}$. A high level of biodiversity characterizes the natural microbiota of traditional Pecorino, in particular the indigenous microorganisms present in milk and coming from the environment during milking and cheesemaking, have a role in the cheese ripening. Figure 2 shows the concentration range among the prevalent microbial groups (Di Cagno et al., 2003; Gardini et al., 2006; Lanciotti et al., 2007; Schirone et al., 2011). Generally high numbers of total mesophilic bacteria have been reported in Pecorino cheeses.

\section{LACTIC ACID BACTERIA}

The main groups detected are LAB, lactococci, and enterococci that are associated with streptococci, mesophilic and thermophilic lactobacilli (represented by Lactobacillus paracasei, Lactobacillus plantarum, Lactobacillus pentosus, Lactobacillus rhamnosus, Lactobacillus curvatus), and other microbial groups (Bizzarro et al., 2000; Randazzo et al., 2006; Vernile et al., 2007). In traditional cheeses $S$. thermophilus has been isolated up to $9 \log \mathrm{cfu} / \mathrm{g}$ at 1 month of ripening, in particular from Pecorino Sardo (Pisano et al., 2006; Comunian et al., 2010). Recently a strain of $S$. thermophilus has been found to have a tyrosine decarboxylase gene $(t d c A)$, that appear to be a horizontal gene transfer event from $t d c A$ of $L$. curvatus (La Gioia et al., 2011). 


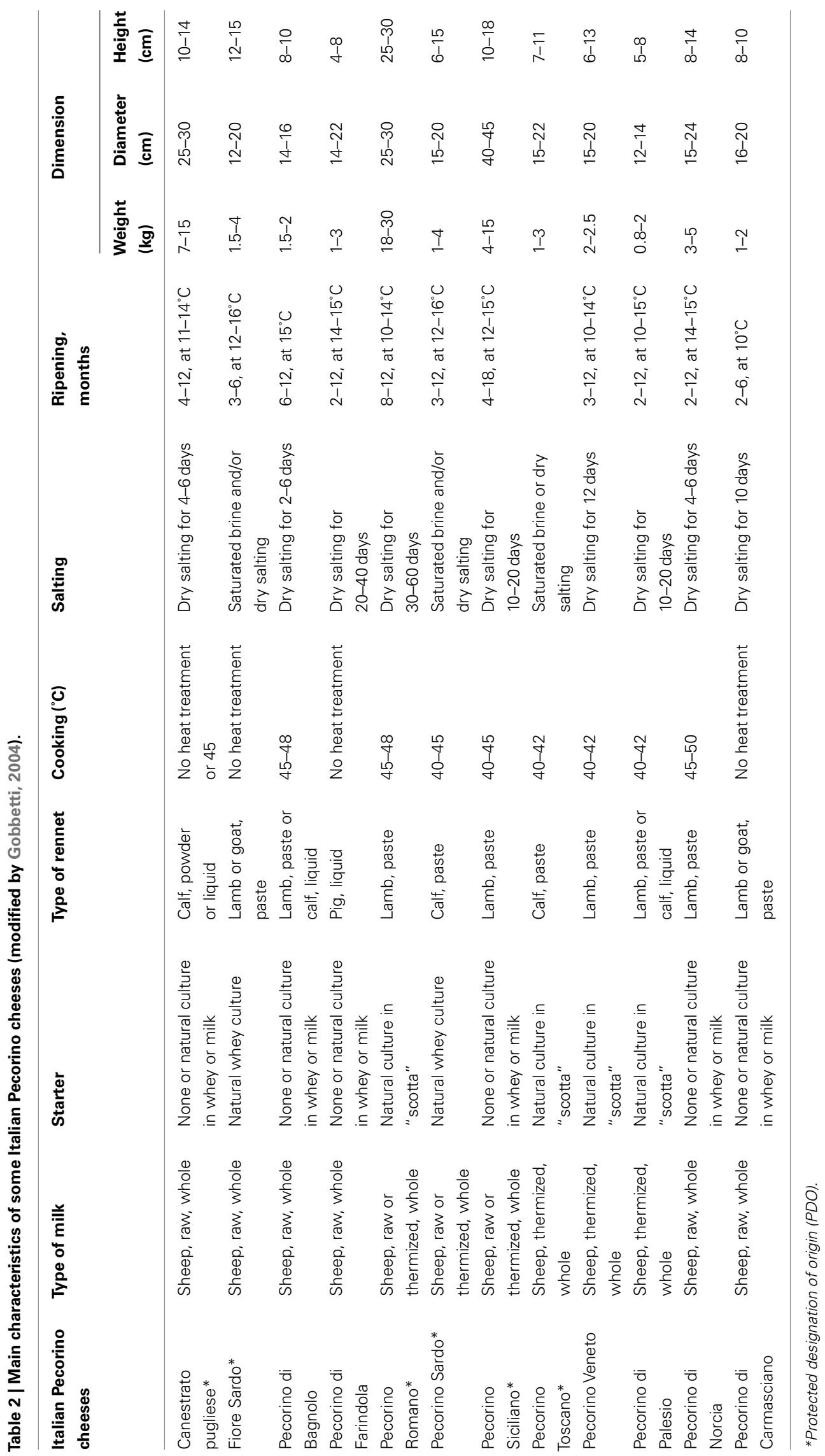




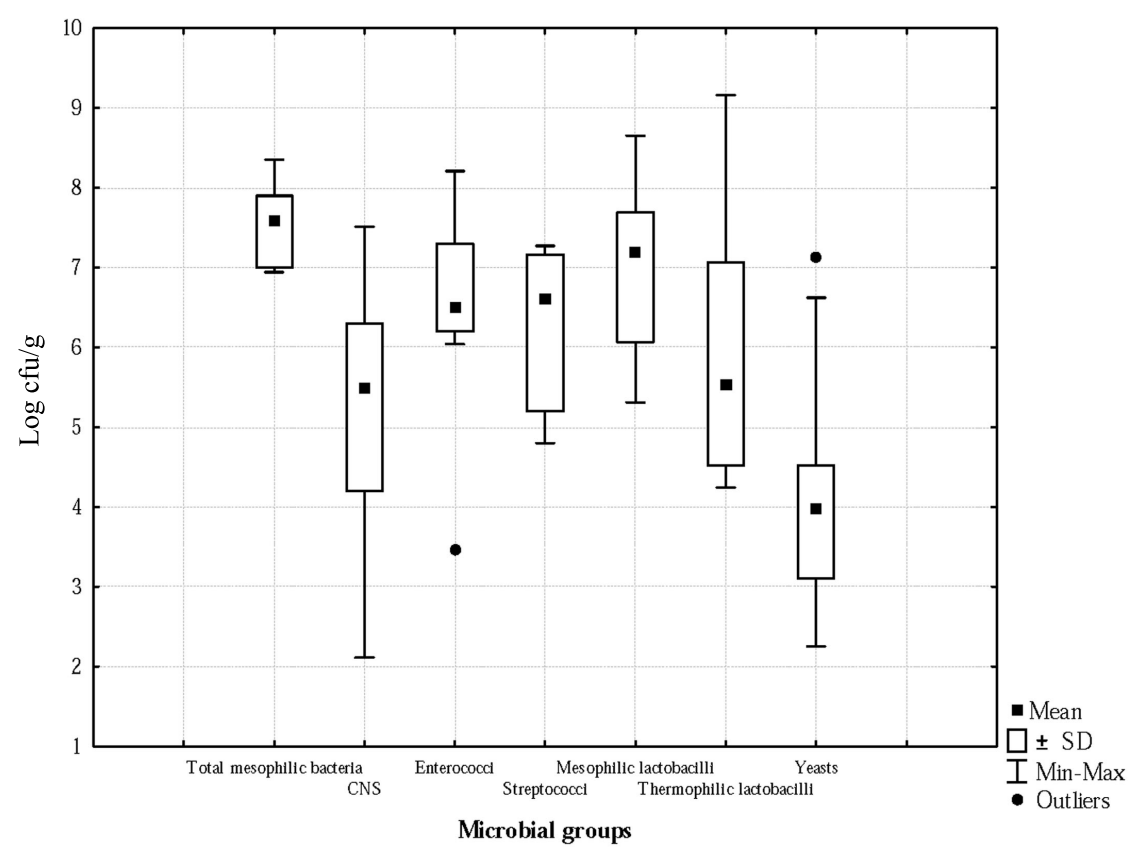

FIGURE 2 | Principal microbial groups in some Italian Pecorino cheeses.

Enterococci represent a typical microbiota of ewe's milk, with Enterococcus faecium and Enterococcus faecalis being the most prevalent ones (Gonzàlez De Llano et al., 1992; Centeno et al., 1995; Giraffa et al., 1997; Martín-Platero et al., 2009). Generally their numbers increase during ripening from $10^{6}$ to $10^{8} \mathrm{cfu} / \mathrm{g}$ in the final product. In the 24 -h-old cheese, LAB belonging to Lactococcus lactis are the major components and reached $10^{9} \mathrm{cfu} / \mathrm{g}$, while the enterococci represent $1-10 \%$ of the total microbiota (Bizzarro et al., 2000). During ripening, the level of lactococci decrease, while the enterococci maintain a constant number, so that the enterococci may become the most important group. They constitute part of the normal food microbiota and play an important role in manufacture of cheeses typical from mediterranean countries (Ledda et al., 1994; Arizcun et al., 1997; Franz et al., 1999, 2003; Mannu et al., 1999; Gomez et al., 2000; Prodromou et al., 2001; Mannu and Paba, 2002; Foulquié Moreno et al., 2006; Pisano et al., 2007; Ogier and Serror, 2008). In Pecorino cheese enterococci constitute a relevant part of the cheese microbiota (Figure 2). Gelsomino et al. (2002) have demonstrated that enterococci survive and grow in the hidden corners of the milking machine and the bulk tank, thus contaminating the milk directly. From the milk, the enterococci are transferred into the cheese. Regarding BA production, Suzzi et al. (2000) found that great part of enterococci isolated from Semicotto caprino cheese produce tyramine but not histamine in synthetic medium. These data are in agreement with those of Giraffa et al. (1995) and Celano et al. (1992) who found that tyramine was the only BA produced by enterococci in milk.

\section{NON-STARTER LACTIC ACID BACTERIA}

Non-starter lactic acid bacteria (NSLAB) dominate the microbiota of Pecorino cheeses made from raw milk than in those made from pasteurized milk (Fox, 1998). In the early phase of manufacture NSLAB are present at very low numbers, but they increase throughput ripening and the major part of Pecorino cheeses has $>6.0 \log \mathrm{cfu} / \mathrm{g}$ at the end of the process (Coda et al., 2006). In fact indigenous NSLAB have the unique ability to grow under highly selective conditions prevailing in a cheese ripening and have been shown to contribute to the formation of small peptides and amino acids that are precursors for the flavor components but also for BA formation (Wouters et al., 2002).

\section{ENTEROBACTERIACEAE}

Enterobacteriaceae are not commonly detected in the final product due to their gradual decrease during cheese ripening (Medina et al., 1991; Hatzikamari et al., 1999; Dahl et al., 2000). However, high numbers of Enterobacteriaceae have been reported in different mediterranean cheeses made from ewes' and goats' raw milk after 30 days of ripening (Sánchez-Rey et al., 1993; Freitas et al., 1995, 1996; Freitas and Malcata, 2000; Psoni et al., 2003; Macedo et al., 2004). In Pecorino Abruzzese Enterobacteriaceae can be detected after 15 days of ripening at levels of $10^{3}$ and $10^{5} \mathrm{cfu} / \mathrm{g}$ in spring and summer, respectively, and are still present $\left(10^{2} \mathrm{cfu} / \mathrm{g}\right)$ after 60 days (Chaves-López et al., 2006). According to previous data obtained from Enterobacteriaceae inoculated in UHT milk (Chaves-López et al., 2006), the strains from Pecorino Abruzzese produced high quantities of putrescine but only small or undetectable quantities of cadaverine. Moreover, histamine was produced by all the strains. Many Enterobacteriaceae can produce considerable levels of histamine in fermented foods and particularly Enterobacter cloacae, Enterobacter aerogenes, and Klebsiella oxytoca, as well as Escherichia coli and Morganella morganii (Suzzi and Gardini, 2003). Although these microorganisms are usually present in low numbers in the 
final product, Enterobacteriaceae can release their decarboxylases in the early steps of cheesemaking (Bover-Cid et al., 2001).

\section{OTHER MICROORGANISMS}

In some cases, psychrotrophic microorganisms and Staphylococcus aureus have been reported (Palmas et al., 1999), indicating a possible contamination and a poor hygiene during manufacturing. Generally coagulase negative staphylococci (CNS) are represented by non-pathogenous species, saprophytic, or useful for conferring typical characteristics to the cheese, such as Staphylococcus xylosus (Palmas et al., 1999). The secondary adventitious microbiota belong to the CNS ranging from about $10^{2}$ to $10^{8} \mathrm{cfu} / \mathrm{g}$ and yeasts ranging from about $10^{2}$ to $10^{7} \mathrm{cfu} / \mathrm{g}$. In Pecorino Crotonese Kluyveromyces lactis and Debaryomyces hansenii strains were found to dominate during the later stages of maturation. Some strains of Yarrowia lipolytica resulted in the highest aminobiogenic potential decarboxylating ornithine, phenylalanine, tyrosine, and lysine (Gardini et al., 2006).

\section{PHYSICO-CHEMICAL FACTORS ON BA FORMATION}

Other extrinsic factors may play an important role in the accumulation of $\mathrm{BA}$ in cheese, e.g., $\mathrm{pH}$, salt concentration, water activity, and redox potential (Pinho et al., 2001). In Table 3 the physicochemical characteristics of Pecorino cheese are reported. The range values for some parameters are very large, indicating important differences during the manufacturing and the ripening conditions of Pecorino cheeses. For example $\mathrm{NaCl}$ concentration ranges from 1 to $9 \%$, because some cheeses are salted by immersion in $\mathrm{NaCl}$ brine or by application of salt crystals at different times. This parameter could influence water activity, enzyme activity, and microbial dynamics (Fox and Guinee, 1987; Van der Berg and Exterkate, 1993). The $\mathrm{NaCl}$ concentration in milk slows down the formation of different amines such as agmatine, spermine, spermidine, putrescine, histamine, tyramine, and tryptamine (Santos et al., 2003).

Then, the characteristics of a Pecorino cheese depend on microbiota dynamics. Both starter and secondary microbiota modify the physico-chemical properties of cheese. Each cheese type should be studied particularly, given the high variability in physico-chemical composition. Then, the quality of raw milk, the environmental conditions, and the traditional manufacture play an important role in determining the characteristics of an artisanal Pecorino cheese. Characterizing cheese microbial population may contribute to understand the ecological processes that drive microbial

Table 3 | Range of the gross chemical composition in Italian Pecorino cheeses (modified by Gobbetti, 2004).

\begin{tabular}{ll}
\hline & Parameters \\
\hline Moisture $(\% \mathrm{w} / \mathrm{w})$ & $30-34$ \\
Fat $(\% \mathrm{w} / \mathrm{w})$ & $27-32$ \\
$\mathrm{NaCl}(\% \mathrm{w} / \mathrm{w})$ & $1-9$ \\
Protein $(\% \mathrm{w} / \mathrm{w})$ & $25-32$ \\
Ash $(\%)$ & $1-3$ \\
Soluble $\mathrm{N} /$ Total $\mathrm{N}(\%)$ & $20-28$ \\
$\mathrm{pH}$ & $5.1-5.5$
\end{tabular}

interaction in cheese and their technological relevance. Knowledge of the structure and dynamics of the whole microbial community of cheese would promote better understanding of BA's formation with respect to microbial growth and metabolism.

\section{BIOGENIC AMINES IN PECORINO CHEESES}

The presence of relevant amounts of BA in cheeses has been recently documented for a few types of Pecorino cheeses (Martuscelli et al., 2005; Lanciotti et al., 2007; Del Signore and Di Giacomo, 2008; Mascaro et al., 2010; Mercogliano et al., 2010; Bavazzano et al., 2011; Forzale et al., 2011; Schirone et al., 2011). In these studies the quantitative and qualitative accumulation of such compounds was extremely variable (Table 4 ). The diamines, putrescine and cadaverine, were found in higher concentrations in Pecorino di Fossa and Pecorino di Farindola. In particular, Mascaro et al. (2010) in Pecorino di Fossa found values of 579.60 and $1302.86 \mathrm{mg} / \mathrm{kg}$ for putrescine and cadaverine, respectively; while in samples of Pecorino di Farindola, putrescine ranged from 9.9 to $394 \mathrm{mg} / \mathrm{kg}$ and cadaverine from 26.8 to $276.1 \mathrm{mg} / \mathrm{kg}$ (Schirone et al., 2011). Tyramine was always present at high concentrations compared with the other amines of the same cheese. Among ten batches of Pecorino di Farindola (Schirone et al., 2011) tyramine resulted to be the BA present in the highest concentration in all cheeses examined, representing in six samples more than $40 \%$ of the total amines. A high relationship between tyramine and total BA content in Pecorino di Farindola cheese was found $\left(R^{2}=0.9869\right)$. High values of this BA have been determined also in Pecorino di Fossa, Pecorino Abruzzese and Pecorino di MigliarinoSan Rossore, particularly in the cheese core $(1300 \mathrm{mg} / \mathrm{kg})$. The relevant incidence of tyramine in cheese manufactured from raw ewes' milk has been reported (Roig-Saguès et al., 2002; Martuscelli et al., 2005; Pintado et al., 2008; Ladero et al., 2010).

Tyramine-producing bacterial strains are expected to be present in Pecorino especially within the groups of NSLAB, Enterobacteriaceae and enterococci, as indicated in the study of Martuscelli et al. (2005). The high level of tyramine in the Pecorino cheese could be due to the activity of thermoresistant enterococci, usual contaminants of raw milk. However, the heat resistance at more than $65^{\circ} \mathrm{C}$ of some Lactobacillus species, and in particular of L. paracasei, has been demonstrated (Jordan and Cogan, 1999). There is evidence that LAB are occasionally associated with tyramine formation, although they can also contribute to the accumulation of other BA such as putrescine. On the contrary, Enterobacteriaceae would be associated with cadaverine, putrescine, and histamine formation, mainly when a deterioration process occurs in either raw materials or end products (Marino et al., 2003). It is well known that BA accumulation in cheese can be influenced, firstly by the microbial quality of raw milk, the sanitation procedures adopted, the use of starter cultures, and the condition and time of the ripening process (Novella-Rodríguez et al., 2004; Pinho et al., 2004). The differences detected in BA accumulation could be attributable to the milk used, probably because of the heterogeneity of the cheese typology considered. An analogous heterogeneity in BA content was observed by Novella-Rodríguez et al. (2003) in cheeses from bovine milk. The microbial population of raw milk can influence BA presence in cheese, even when thermal treatment are applied such as for a Pecorino cheese (Lanciotti et al., 2007) or for Pecorino Abruzzese (Martuscelli et al., 2005). It can 


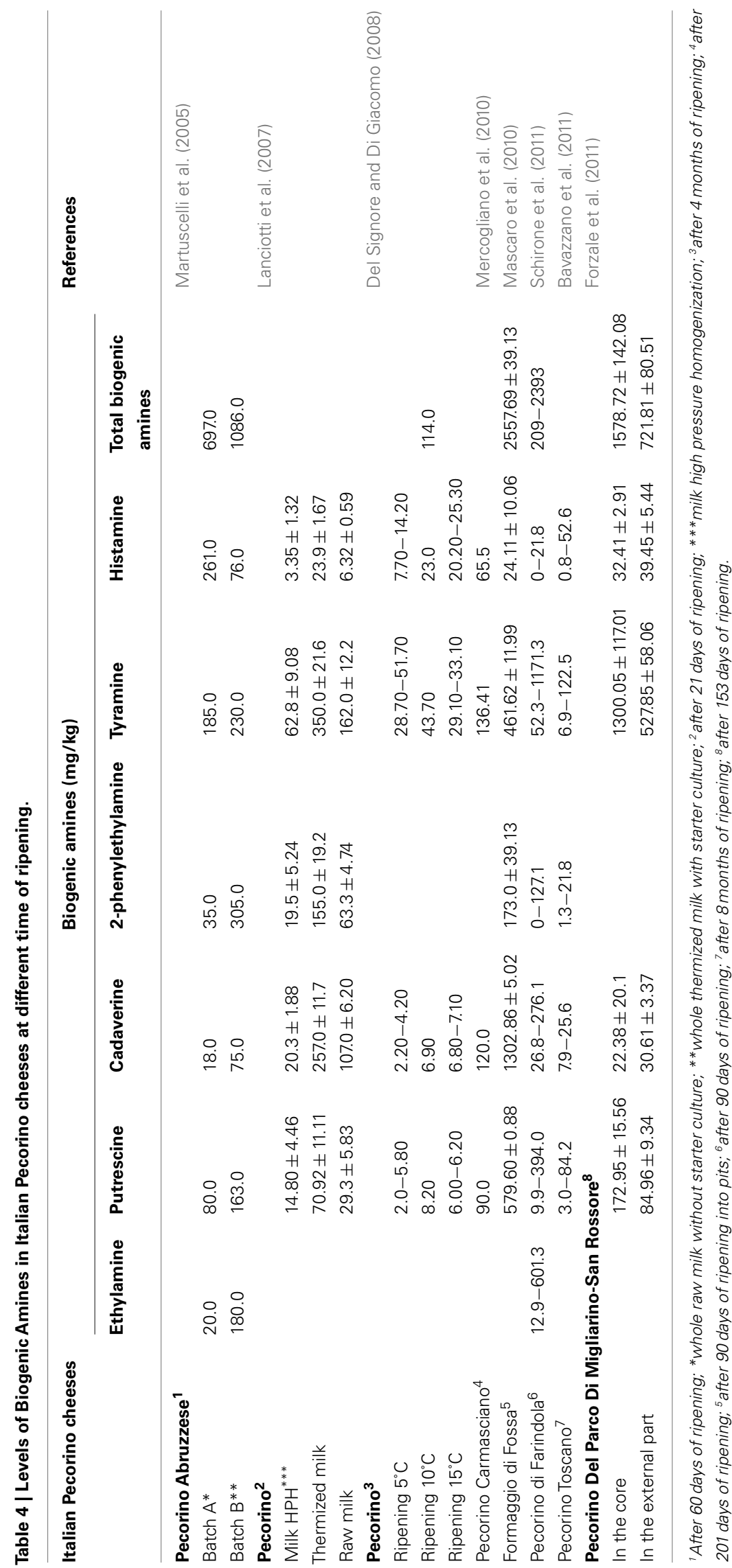


be hypothesized that the mild thermal treatment applied selects a decarboxylating microbial population, which dominates during cheesemaking and, possibly, during ripening. Similar results have been reported by Marino et al. (2008) showing the highest BA contents in cheese produced using pasteurized milk and natural milk culture; therefore, the thermal treatment of milk seems to be not enough by itself to reduce the counts of decarboxylase-positive bacteria in cheese. However, other authors observed a higher BA accumulation in cheeses obtained from raw milk than in similar products from pasteurized milk (Schneller et al., 1997).

Cheese is a matrix with a high protein content in which their demolition to free amino acids (or short peptides) is guaranteed by proteases or peptidases produced by microorganisms (including starter cultures), present in milk (especially if not thermally treated), and/or in rennet. Given these activities, the availability of precursors is not a central problem in BA accumulation (Lanciotti et al., 2007). Fernández-García et al. (2000) studied the influence of addition of exogenous proteinases to milk and found that tyramine concentration was significantly $(P<0.05)$ influenced by this addition.

The high content of BA in many Pecorino cheeses could be due, in part, to proteinases, and peptidases released from rennet used, particularly artisanal lamb rennets, or pig rennet during cheesemaking of Pecorino di Farindola. In fact the traditional lamb paste preparation procedure has a significant impact on rennet composition, as has animal age, precedent diet, or slaughtering condition (Jacob et al., 2011). In artisanal lamb paste production, there is a substantial microbiota, dominated by LAB (Etayo et al., 2006; Gil et al., 2007). The use of artisanal rennets often entails problems concerning curd formation and final characteristics of the cheese. Vincente et al. (2001) reported that the release of free amino acids during ripening is strongly affected by starter added to the cheese, and that this effect varies markedly with the rennet used for cheesemaking. However the level of starter culture does

\section{REFERENCES}

Arizcun, C., Barcina, Y., and Torre, P. (1997). Identification and characterization of proteolytic activity of Enterococcus spp. isolated from milk and Roncal and Idiazabal cheese. Int. J. Food Microbiol. 38, 17-24.

Bavazzano, P., Boccetti, M., Cianti, L., Colzi, A., Leandri, A., Munaò, G., and Perico, A. (2011). Indagine sulla prevalenza delle amine biogene nel Pecorino toscano D.O.P. stagionato. Associazione Italiana Veterinari Igienisti 1, 197-201.

Beresford, T. P., Fitzsimons, N. A., Brennan, N. L., and Cogan, T. M. (2001). Recent advances in cheese microbiology. Int. Dairy J. 11, 259-274.

Bizzarro, R., Tarelli, G. T., Giraffa, G., and Neviani, E. (2000). Phenotypic and genotypic characterization of lactic acid bacteria isolated from Pecorino Toscano cheese. Ital. J. Food Sci. 12, 303-316.
Bover-Cid, S., Izquierdo-Pulido, M., and Vidal-Carou, C. (2001). Effect of the interaction between a low tyramine-producing Lactobacillus and proteolytic staphylococci on biogenic amine production during ripening and storage of dry sausages.

Caridi, A., Micari, P., Caparra, P., Curari, A., and Sarullo, V. (2003). Ripening and seasonal changes in microbial groups and in physicochemical properties of the ewes' cheese Pecorino del Poro. Int. Dairy J. 13, 191-200.

Celano, G. V., Cafarchia, C., Buja, F., and Tiecco, G. (1992). Ricerca di amine biogene in alcuni formaggi. Ind. Aliment. 31, 764-768.

Centeno, J. A., Cepeda, A., and Rodríguez-Otero, J. L. (1995). Identification and preliminary characterization of strains of enterococci and micrococci isolated from Arzúra raw cows'-milk cheese. Nahrung 39, 55-62. Int. J. Food Microbiol. 65, 113-123.

not appears to affect the population of tyrosine decarboxylase microorganisms (Fernández-García et al., 2000). As a consequence of this, the natural whey starter used for Pecorino cheese manufacture and the rennet could affect the quality, the quantities, and variability of BA accumulation.

\section{CONCLUSION}

Pecorino cheeses, ewe's milk dairy products of many Italian regions, have an important link with their areas of production which confer on them specific microbiological, chemical, and sensorial characteristics (Pirisi et al., 2011). The spread use of raw milk creates a high microbiological biodiversity, such as the use of different traditional rennets contribute to typical aromas and flavors. The presence of high contents of BA in Pecorino cheeses could be related to the enzymatic activity of proteases derived from microorganisms, or from another origin (rennet) that is important from a qualitative point of view, i.e., in relation to the type of amino acids provided to the amino acid decarboxylating microbiota, in particular tyrosine. The bacteriological composition of milk could be critical to define the BA profile in this type of cheese, that is generally produced in little farms. Even though Pecorino cheese is very important from economical point of view in certain Italian areas, studies on BA content and their origin are still scarce. Therefore, large amounts of BA in cheese could indicate unsuitability, from a hygienic point of view, of the milk used for cheesemaking. The need to know in depth and control the indigenous bacterial population responsible for high production of BA and the use of competitive adjunct cultures could be useful to improve the characteristics of Pecorino cheese.

\section{ACKNOWLEDGMENTS}

This research line has received funding from Cassa di Risparmio di Teramo (Rapid methods to determine and quantify tyramine content in dairy products of Abruzzo region).

Chaves-López, C., De Angelis, M., Martuscelli, M., Serio, A., Paparella, A., and Suzzi, G. (2006). Characterization of the Enterobacteriaceae isolated from an artisanal Italian ewe's cheese (Pecorino Abruzzese). J. Appl. Microbiol. 101, 353-360.

Clementi, F., Cenci Goga, B. T., and Di Antonio, E. (1994). Onfarm manufactured Pecorino cheese. Evaluation of the microbiological characteristics of milk and cheese in Umbria (Italy). Latte 19, 575.

Coda, R., Brechany, E., De Angelis, M., De Candia, S., Di Cagno, R., and Gobbetti, M. (2006). Comparison of the compositional, microbiological biochemical, and volatile profile characteristics of nine Italian ewes' milk cheeses. J. Dairy Sci. 89, 4126-4143.

Comunian, R., Paba, A., Daga, E., Dupré, I., and Scintu, M. F. (2010). Traditional and innovative production methods of Fiore Sardo cheese: a comparison of microflora with a PCR-culture technique. Int. J. Dairy Technol. 63, 224-233.

Corroler, D., Mangin, I., Desmasures, N., and Gueguen, M. (1998). An ecological study of lactococci isolated from raw milk in the Camembert cheese registered designation of origin area. Appl. Environ. Microbiol. 64, 4729-4735.

Dahl, S., Tavaria, F. K., and Malcata, F. X. (2000). Relationship between flavour and microbiological profiles in Serra da Estrela cheese throughout ripening. Int. Dairy J. 10, 255-262.

Del Signore, A., and Di Giacomo, F. (2008). Technological factor influencing the biogenic amine content in sheep cheeses and sensorial analysis (time of ripening, temperature, form size, anti-mould). $J$. Commodity Sci. Technol. Qual. 47, 229-243. 
Di Cagno, R., Banks, J., Sheehan, L., Fox, P. F., Brechany, E. Y., Corsetti, A., and Gobbetti, M. (2003). Comparison of the microbiological, compositional, biochemical, volatile profile and sensory characteristics of three Italian PDO ewes' milk cheeses. Int. Dairy J. 13, 961-972.

Etayo, I, Perez Elortondo, F. J., Gil, P. F., Albisu, M., Virto, M., Conde, S., Rodriguez Barron, L. J., Nájera, A. I., Gómez-Hidalgo, M. E., Delgado, C., Guerra, A., and De Renobales, M. (2006). Hygienic quality, lipolysis and sensory properties of Spanish protected designation of origin ewe's milk cheeses manufactured with lamb rennet paste. Lait 86, 415-434.

Fernández-García, E., Tomillo, J., and Nuñez, M. (2000). Formation of biogenic amines in raw milk Hispánico cheese manufactured with proteinases and different levels of starter culture. J. Food Prot. 63, 1551-1555.

Forzale, F., Giorgi, M., Pedonese, F., Nuvoloni, R., D'Ascenzi, C., and Rindi, S. (2011). Contenuto di amine biogene nel "Pecorino del parco di Migliarino-San Rossore." Associazione Italiana Veterinari Igienisti 1, 149-153.

Foulquié Moreno, M. R., Sarantinopoulos, P., Tsakalidou, E., and De Vuyst, L. (2006). The role and application of enterococci in food and health. Int. J. Food Microbiol. 106, 1-24.

Fox, P. F. (1998). "Developments in biochemistry of cheese ripening," in Proceedings of Dairy Science and Technology 25th International Dairy Congress, Aarhus, 11-37.

Fox, P. F., and Guinee, T. P. (1987). "Italian cheeses," in Cheese: Chemistry, Physics and Microbiology, ed. P. F. Fox (London: Elsevier Applied Science), 221.

Franz, C. M. A. P., Holzapfel, W. H., and Stiles, M. E. (1999). Enterococci at the crossroads of food safety. Int. J. Food Microbiol. 47, 1-24.

Franz, C. M. A. P., Stiles, M. E., Schleifer, K. H., and Holzapfel, W. H. (2003). Enterococci in foods - a conundrum from food safety. Int. J. Food Microbiol. 88, 105-122.

Freitas, A. C., and Malcata, F. X. (2000). Microbiology and biochemistry of cheeses with appellation d'origine protege 'e and manufactured in the Iberian Peninsula from ovine and caprine milks. J. Dairy Sci. 83, 584-602.

Freitas, A. C., Pais, C., Malcata, F. X., and Hogg, T. A. (1996). Microbiological characterization of Picante da
Beira Baixa cheese. J. Food Prot. 59, 155-160.

Freitas, A. C., Sousa, M. J., and Malcata, F. X. (1995). Effect of ripening time and the combination of ewe and goat milk on the microflora of Picante cheese. Ital. J. Food Sci. 7, 361-377.

Gardini, F., Tofalo, R., Belletti, N., Iucci, L., Suzzi, G., Torriani, S., Guerzoni, M. E., and Lanciotti, R. (2006). Characterization of yeasts involved in the ripening of Pecorino Crotonese cheese. Food Microbiol. 23, 641-648.

Gelsomino, R., Vancanneyt, M., Cogan, T. M., Condon, S., and Swings, J. (2002). Source of enterococci in a farmhouse raw-milk cheese. Appl. Environ. Microbiol. 68, 3560-3565.

Gil, P. F., Conde, S., Albisu, M., PerezElortondo, F. J., Etayo, I., Virto, M., and de Renobales, M. (2007). Hygienic quality of ewes' milk cheeses manufactured with artisanproduced lamb rennet pastes. J. Dairy Res. 74, 329-335.

Giraffa, G., Carminati, D., and Neviani, E. (1997). Enterococci isolated from dairy products: a review of risks and potential tech-nological use. J. Food Prot. 60, 732-738.

Giraffa, G., Pepe, G., Locci, F., Neviani, E., and Carminati, D. (1995). Haemolytic activity, production of thermonuclease and biogenic amines by dairy enterococci. Ital. J. Food Sci. 7, 339-347.

Gobbetti, M. (2004). "Extra-hard varities," in Cheese Chemistry, Physics and Microbiology, Vol. 2, eds P. F. Fox, P. L. H. McSweeney, T. M. Cogan, and T. P. Guinee (London: Academic Press), 51-70.

Gobbetti, M., Corsetti, A., Smacchi, E., De Angelis, M., and Rossi, J. (1997). Microbiology and biochemistry of Pecorino Umbro cheese during ripening. Ital. J. Food Sci. 9, 111-126.

Gomez, R., Vioque, M., Sanchez, E., Mata, C., Tejada, L., and FernandezSalguero, J. (2000). Microbial study of farmhouse ewe cheese during storage in olive oil. Acta Microbiol. Immun. Hung. 47, 53-61.

Gonzàlez De Llano, D., Ramos, M., Rodríguez, A., Montilla, A., and Juárez, M. (1992). Microbiological and physicochemical characteristics of Gamonedo blue cheese during ripening. Int. Dairy J. 2, 121-125.

Hatzikamari, M., LitopoulouTzanetaki, E., and Tzanetakis, N. (1999). Microbiological characteristics of Anevato: a traditional Greek cheese. J. Appl. Microbiol. 87, 595-601.
Jacob, M., Jaros, D., and Rohm, H. (2011). Recent advances in milk clotting enzymes. Int. J. Dairy Technol. 64, 14-33.

Jordan, K. N., and Cogan, T. M. (1999). Heat resistance of Lactobacillus spp. isolated from Cheddar cheese. Lett. Appl. Microbiol. 29, 136-140.

La Gioia, F., Rizzotti, L., Rossi, F., Gardini, F., Tabanelli, G., and Torriani, S. (2011). Identification of a tyrosine decarboxylase gene (tdcA) in Streptococcus thermophilus 1TT45 and analysis of its expression and tyramine production in milk. Appl. Environ. Microbiol. 77, 1140-1144.

Ladero, V., Martínez, N., Martín, M. C. Fernández, M., and Alvarez, M. A. (2010). qPCR for quantitative detection tyramine-producing bacteria in dairy products. Food Res. Int. 43, 289-295.

Lanciotti, R., Patrignani, F., Iucci, L., Guerzoni, M. E., Suzzi, G., Belletti, N., and Gardini, F. (2007). Effects of milk high pressure homogenization on biogenic amine accumulation during ripening of ovine and bovine Italian cheeses. Food Chem. 104, 693-701.

Ledda, A., Scintu, M. F., Pirisi, A., Sanna, S., and Mannu, L. (1994). Caratterizzazione tecnologica di ceppi di lattococchi e di enterococchi per la produzione di formaggio pecorino Fiore Sardo. Scienza e Tecnica Lattiero Casearia 45, 443-456.

Macedo, A. C., Tavares, T. G., and Malcata, F. X. (2004). Influence of native lactic acid bacteria on the microbiological, biochemical and sensory profiles of Serra da Estrela cheese. Food Microbiol. 21, 233-240.

Mannu, L., and Paba, A. (2002). Genetic diversity of lactococci and enterococci isolated from home-made Pecorino Sardo ewes' milk cheese. J. Appl. Microbiol. 92, 55-62.

Mannu, L., Paba, A., Pes, M., Floris, R., Scintu, M. F., and Morelli, L. (1999). Strain typing among enterococci isolated from home-made Pecorino Sardo cheese. FEMS Microbiol. Lett. 170, 25-30.

Marino, M., Maifreni, M., Bartolomei, I., and Rondinini, G. (2008). Evaluation of aminoacid decarboxylative microbiota throughout the ripening of an Italian PDO cheese produced using different manufacturing practices. J. Appl. Microbiol. 105, 540-549.

Marino, M., Maifreni, M., and Rondinini, G. (2003). Microbiological characterization of artisanal Montasio cheese: analysis of its indigenous lactic acid bacteria. FEMS Microbiol. Lett. 229, 133-140.
Martín-Platero, A. M., Valdivia, E., Maqueda, M., and Martínez-Bueno, M. (2009). Characterization and safety evaluation of enterococci isolated from Spanish goats' milk cheeses. Food Microbiol. 132, 24-32.

Martuscelli, M., Gardini, F., Torriani, S., Mastrocola, D., Serio, A., Chaves-Lopez, C., Schirone, M., and Suzzi, G. (2005). Production of biogenic amines during the ripening of Pecorino Abruzzese cheese. Int. Dairy J. 15, 571-578.

Mascaro, N., Stocchi, R., Ricciutelli, M., Cammertoni, N., Renzi, F., Cecchini, S., Loschi, A. R., and Rea, S. (2010). Biogenic amine content and chemical and physical features of italian formaggio di Fossa. Associazione Italiana Veterinari Igienisti 8, 49-53.

Medina, M., Fernández del Pozo, B. M., Rodríguez-Marín, A., Gaya, P., and Nuñez, M. (1991). Effect of lactic starter inoculation on chemical, microbiological, rheological and sensory characteristics of La Serena cheese. J. Dairy Res. 58, 355-361.

Mercogliano, R., De Felice, A., Chirollo, C., and Cortesi, M. L. (2010). Production of vasoactive amines during the ripening of Pecorino Carmasciano cheese. Vet. Res. Commun. 34, S175-S178.

Novella-Rodríguez, S., Veciana-Nogués, M. T., Izquierdo-Pulido, M., and Vidal-Carou, M. C. (2003). Distribution of biogenic amines and polyamines in cheese. J. Food Sci. 68, 750-756.

Novella-Rodríguez, S., Veciana-Nogue, M. T., Artur Roig-Sagues, X., Antonio, A. X., Trujillo-Mesa, J. A. T., Carmen, M., and Vidal-Carou, M. C. (2004). Evaluation of biogenic amines and microbial counts throughout the ripening of goat cheeses from pasteurized and raw milk. J. Dairy Res. 71, 245-252.

Ogier, J. C., and Serror, P. (2008). Safety assessment of dairy microorganisms - the Enterococcus genus. Int. J. Food Microbiol. 126, 291-301.

Palmas, F., Cosentino, S., Fadda, M. E., Deplano, M., and Mascia, V. (1999). Microbial characteristics of Pecorino processed cheese spreads. Lait 79, 607-713.

Pinho, O., Ferreira, I. M. P. L. V. O., Mendes, E., Oliveira, B. M., and Ferreira, M. (2001). Effect of temperature on evolution of free amino acid and biogenic amine contents during storage of Azeitao cheese. Food Chem. 75, 287-291.

Pinho, O., Pintado, A. I. E., Gomes, A. M. P., Pintado, M. M. E., Malcata, F. X. and Ferreira, I. M. P. L. V. O. (2004). 
Interrelationships among microbiological physico-chemical, and biochemical properties of Terrincho cheese, with emphasis on biogenic amines. J. Food Prot. 67, 2779-2785.

Pintado, A. I. E., Pinho, O., Ferreira, I. M. P. L. V. O., Pintado, M. M. E., Gomes, A. M. P., and Malcata, F. X. (2008). Microbiological, biochemical and biogenic amine profiles of Terrincho cheese manufactured in several dairy farms. Int. Dairy J. 18,631-640.

Pirisi, A., Comunian, R., Urgeghe, P. P., and Scintu, M. F. (2011). Sheep's and goat's dairy products in Italy: technological, chemical, microbiological, and sensory aspects. Small Rum. Res. 101, 102-112.

Pisano, M. B., Fadda, M. E., Deplano, M., Corda, A., Casula, M., and Cosentino, S. (2007). Characterization of Fiore Sardo cheese manufactured with the addition of autochthonous cultures. J. Dairy Res. 74, 255-261.

Pisano, M. B., Fadda, M. E., Deplano, M., Corda, A., and Cosentino, S. (2006). Microbiological and chemical characterization of Fiore Sardo, a traditional Sardinian cheese made from ewe's milk. Int. J. Dairy Technol. 59, 171-179.

Poznanski, E., Cavazza, A., Cappa, F., and Cocconcelli, P. S. (2004). Indigenous raw milk microbiota influences the bacterial developent in trditional cheese from alpine natural park. Int. J. Food Microbiol. 92, 141-151.
Prodromou, K., Thasitou, P., Haritonidou, E., Tzanetakis, N., and Litopoulou-Tzanetaki, E. (2001). Microbiology of "Orinotyri," a ewe's milk cheese from the Greek mountains. Food Microbiol. 18,319-328.

Psoni, L., Tzanetakis, N., and Litopoulou-Tzanetaki, E. (2003). Microbiological characteristics of Batzos, a traditional Greek cheese from raw goat's milk. Food Microbiol. 20, 575-582.

Randazzo, C. L., Vaughan, E. E., and Caggia, C. (2006). Artisanal and experimental Pecorino Siciliano cheese: microbial dynamics during manufacture assessed by culturing and PCR-DGGE analyses. Int. J. Food Microbiol. 109, 1-8.

Ricci, C., Bucchianico, R., D’Angelo, M. G., Trivillino, R., Torriani, S., and Dellaglio, F. (1995). Production of Pecorino d'Abruzzo cheese: characteristics of finished product and aspects of the ripening process. Latte 20, 268-274.

Roig-Saguès, A. X., Molina, A. P., and Hernandez-Herrero, M. M. (2002). Histamine and tyramine-forming microorganisms in Spanish traditional cheeses. Eur. Food Res. Technol. 215, 96-100.

Sánchez-Rey, R., Poullet, B., Cáceres, P., and Larriba, G. (1993). Microbiological quality and incidence of some pathogenic microorganisms in $\mathrm{La}$ Serena cheese throughout ripening. J. Food Prot. 56, 879-881.

Santos, W. C., Souza, M. R., Cerqueira, M. M. O. P., and Glória, M. B. A.
(2003). Bioactive amines formation in milk by Lactococcus in the presence or not of rennet and $\mathrm{NaCl}$ at 20 and $32^{\circ} \mathrm{C}$. Food Chem. 81 , 595-606.

Schirone, M., Tofalo, R., Mazzone, G., Corsetti, A., and Suzzi, G. (2011). Biogenic amine content and microbiological profile of Pecorino di Farindola cheese. Food Microbiol. 28 , 128-136.

Schneller, R., Good, P., and Jenny, M. (1997). Influence of pasteurized milk, raw milk and different ripening cultures on biogenic amine concentrations in semi-soft cheeses during ripening. Z. Lebensm. Unters. Forsch. 204, 265-272.

Suzzi, G., Caruso, M., Gardini, F., Lombardi, A., Vannini, L., Guerzoni, M. E., Andrighetto, C., and Lanorte, M. T. (2000). A survey of enterococci isolated from an artisanal Italian goat's cheese (semicotto caprino). J. Appl. Microbiol. 89, 267-274.

Suzzi, G., and Gardini, F. (2003). Biogenic amines in dry fermented sausages: a review. Int. J. Food Microbiol. 88, 41-54.

Van der Berg, G., and Exterkate, F. A. (1993). Technological parameters involved in cheese ripening. Int Dairy J. 3, 485.

Vernile, A., Beresford, T. P., Spano, G., Massa, S., and Fox, P. F. (2007). Chemical studies of Pecorino Siciliano cheese throughout ripening. Milchwissenschaft 62 , 280-284.
Vincente, M. S., Ibánez, F. C., Barcina, Y., and Barron, L. J. R. (2001). Casein breakdown during ripening of Idiazabal cheese: influence of starter and rennet type. J. Sci. Food Agric. 81, 210-215.

Wouters, J. T. M., Ayad, E. H. E., Hugenholtz, J., and Smit, G. (2002). Microbes from raw milk for fermented dairy products. Int. Dairy J. 12, 91-99.

Conflict of Interest Statement: The authors declare that the research was conducted in the absence of any commercial or financial relationships that could be construed as a potential conflict of interest.

Received: 23 February 2012; paper pending published: 20 March 2012; accepted: 17 April 2012; published online: 08 May 2012.

Citation: Schirone $M$, Tofalo $R$, Visciano P, Corsetti A and Suzzi G (2012) Biogenic amines in Italian Pecorino cheese. Front. Microbio. 3:171. doi: 10.3389/fmicb.2012.00171

This article was submitted to Frontiers in Food Microbiology, a specialty of Frontiers in Microbiology.

Copyright (c) 2012 Schirone, Tofalo, Visciano, Corsetti and Suzzi. This is an open-access article distributed under the terms of the Creative Commons Attribution Non Commercial License, which permits non-commercial use, distribution, and reproduction in other forums, provided the original authors and source are credited. 